Esta revista forma parte del acervo de la Biblioteca Jurídica Virtual del Instituto de Investigaciones Jurídicas de la UNAM

\title{
Originalism's Curiously Triumphant Death: the Interpenetration of Aspirationalism and Historicism in U. S. Constitutional Development*
}

\section{La curiosa muerte triunfante del originalismo: la interpenetración del aspiracionalismo y el historicismo en el desarrollo constitucional estadounidense}

\author{
Ken I. KerSCH**
}

\section{Resumen:}

Uno de los debates centrales entre los constitucionalistas estadounidenses por más de una generación ha sido entre (conservadores) 'originalistas', quienes aseguran que al interpretar y aplicar la constitución los jueces están obligados a adherirse al entendimiento original en el momento en el que la Constitución fue adoptada, y (liberales/progresistas) 'constitucionalistas vivientes', quienes aseveran que cuando sea apropiado, los jueces deberían leer la Constitución a la luz de las necesidades contemporáneas y aspiraciones morales. Aun cuando reconoce la importancia y la legitimidad del llamado originalista a fidelidad a la historia y a los nuevos elementos que incorporan argumentos a sus teoría, Fleming, en Fidelity to Our Imperfect Constitution, reafirma el aspiracionalismo moral como la base última del proyecto interpretivo. Argumento contra Fleming, que la oposición que él (y otros constitucionalistas estadounidenses) han esbozado entre el historicismo del originalismo y el aspiracionalismo moral del constitucionalismo viviente es un binario falso - el producto contingente de la sucesión evolutiva de las batallas políticas entre los conservadores y los liberales/progresistas estadounidenses durante el siglo veinte. Asimismo, alego contra Fleming, que tanto la

* Artículo recibido el 8 de abril de 2016 y aceptado para su publicación el 19 de septiembre de 2016.

** Professor of Political Science, Boston College. A similar version of this article was published in the U.S. under the same title in (2016) 32 Constitutional Commentary 413. I am grateful to all of the participants on the symposium on Jim Fleming's book at la Universidad Nacional Autonoma de Mexico (UNAM) in Mexico City (February 2015), and particularly to Jim and our remarkably capable and gracious host, Imer Flores. 
Esta revista forma parte del acervo de la Biblioteca Jurídica Virtual del Instituto de Investigaciones Jurídicas de la UNAM

KEN I. KERSCH

teoría como la práctica, en al menos los Estados Unidos de América, historia y aspiración moral están y siempre han estado entrelazadas inextricablemente - son inseparables - y que, para ir hacia delante, los historiadores constitucionales y constitucionalistas estadounidenses harían mejor al reconocer y responsabilizarse directamente por este hecho, y su dinámica.

\section{Palabras clave:}

Derecho constitucional, interpretación constitucional, originalismo, constitucionalismo viviente, historicismo, conservadurismo, liberalismo, progresivismo, desarrollo constitucional estadounidense.

\section{Abstract:}

One of the central debates amongst U. S. constitutional theorists for more than a generation has been between (conservative) 'originalists' arguing that, in interpreting and applying the Constitution, judges are duty bound to adhere to the original understandings at the time of the Constitution's adoption and (liberal/progressive) 'living constitutionalists' arguing rather that, when appropriate, judges should read the Constitution in light of contemporary needs and moral aspirations. While acknowledging the significance and legitimacy of the originalist call for fidelity to history and newly incorporating elements of their arguments into his theory, Fleming, in Fidelity to Our Imperfect Constitution, re-affirms moral aspirationalism as the ultimate foundation of the interpretive project. I argue here, as against Fleming, that the opposition that he (and other American constitutional theorists) have drawn between originalism's historicism and living constitutionalism's moral aspirationalism is a false binary - the contingent product of a developmental succession of political battles between American conservatives and progressive/liberals over the course of the twentieth century. I argue here, contra Fleming, that in both theory and practice, in the U. S. at least, history and moral aspiration are and have always been inextricably intertwined -inseparable - and that, going forward, U. S. constitutional historians and theorists would do better by forthrightly acknowledging and accounting for this fact, and dynamic.

\section{Keywords:}

Constitutional interpretation, constitutional law, originalism, living constitutionalism, historicism, conservatism, liberalism, progressivism, U. S. constitutional development. 
Esta revista forma parte del acervo de la Biblioteca Jurídica Virtual del Instituto de Investigaciones Jurídicas de la UNAM

ORIGINALISM'S CURIOUSLY TRIUMPHANT DEATH: THE INTERPENETRATION...

SUMmaRY: I. History in aspirationalism/perfectionism. II. Aspirationalism in historicism. III. Conclusion. IV. Bibliography.

As someone preoccupied with the nature and processes of U. S. constitutional development from an empirical, positivist as opposed to a prescriptive, normative perspective - in is rather than ought - my interest in contemporary constitutional theory of the sort practiced at a high level by Jim Fleming is oblique. I care more about history than theories of justice, about how the Constitution has actually been read to structure public (and private) authority in the U. S. over time than about justifying either the 'best' readings of the parameters of that authority generally, or worrying in particularly about what theory of interpretation can justify a judge in exercising his or her purportedly problematic 'countermajoritarian' powers of judicial review to hold legislation null and void on the grounds that it contravenes the nation's fundamental law. ${ }^{1}$ When I shake my head 'yes' about constitutional theory, it is thus most immediately over what Michael Dorf identifies as the 'eclectic accounts' of Phillip Bobbitt and Richard Fallon, scholars who find, usefully, but not surprisingly, that over the long course of American history, judges have used an array of 'modalities,' or types of arguments, in publicly justifying their decisions in their judicial opinions. ${ }^{2}$ If one moves beyond judicial opinions to constitutional arguments made in the roiling public sphere (parties, elections, social movements, interest groups, and diverse forms of individual and collective legal consciousness, including political and legal claim-making), of course, the modes of argument multiply, and the matter overspills the ambit of professional, institutional justification. ${ }^{3}$ There is a lot of is out there.

1 See Alexander Bickel, The Least Dangerous Branch: The Supreme Court at the Bar of Politics (Bobbs-Merrill 1962) (coining the phrase 'counter-majoritarian difficulty'); Federalist \# 78 (Alexander Hamilton).

2 Bobbitt, Constitutional Fate: Theory of the Constitution (Oxford University Press 1982); Fallon, 'A Constructivist Coherence Theory of Constitutional Interpretation' (1987) 100 Harvard Law Review 1189. See Michael Dorf, 'Integrating Normative and Descriptive Constitutional Theory: The Case of Original Meaning' (1997) 85 Georgetown Law Journal 1765, 1768.

3 See Larry Kramer, The People Themselves: Popular Constitutionalism and Judicial Review (Oxford University Press 2004); J. M. Balkin, Constitutional 
Esta revista forma parte del acervo de la Biblioteca Jurídica Virtual del Instituto de Investigaciones Jurídicas de la UNAM

KEN I. KERSCH

At the same time, however, certainly in the U. S., and perhaps in many other places as well, there is a lot of 'ought' in the 'is'. What has happened is, in significant part, a function of claims made, in various fora about what should happen. There is thus, and always has been, a lot of empirically observable and verifiable 'aspirationalism' in U. S. historical and constitutional development. At the same time, however, there are also a lot of empirically, positivistically verifiable appeals to heritage and history in American aspirationalism, and that aspirationalism also has a history. In light of these dynamics, both aspects of which Fleming helpfully recognizes in Fidelity to Our Imperfect Constitution, Fleming wants to call the fight for aspirationalism. But I think the book as a whole shows that we can call it a draw: there is no reason, or even grounds, for drawing a sharp distinction between one and the other. The extent we feel inclined to do so is an artifact of the trajectory of the living constitutionalist-originalist debates of mid-to-late twentieth century America, debates that Fleming's book demonstrates to me, at least, are, in their most familiar forms, likely not long for this world.

The Living Constitutionalist v. Originalism binary has long seemed to me something of a parlor game: it was always a false opposition, albeit fought out on a scale as large as League of Legends. Fleming (rightly) makes much of the notion of 'originalism as an ism'. But he fails to note that Living Constitutionalism, Aspirationalism, and Constitutional Perfectionism are also 'isms'. The two positions, at least in their contemporary form in recent constitutional theory, born in an age of isms, were mutually constitutive. Fleming's Fidelity to Our Imperfect Constitution aspires to transcend this binary and reconcile in constitutional theory appeals to history and aspiration to the best interpretation. While in the end, he doesn't fully succeed, I do agree with the core of the argument in this book, if not its ultimate conclusion. What pleasantly surprises me is the degree to which

Redemption: Political Faith in an Unjust World (Harvard University Press 2011); George Lovell, This is Not Civil Rights: Discovering Rights Talk in 1939 America (University of Chicago Press 2012); Patricia Ewick and Susan Silbey, The Common Place of Law: Stories from Everyday Life (University of Chicago Press 1998). See Emily Zackin, 'Lost Rights and the Importance of Audience' (Winter 2013) 41 Tulsa Law Review 421. 
Esta revista forma parte del acervo de la Biblioteca Jurídica Virtual del Instituto de Investigaciones Jurídicas de la UNAM

Fleming, a leading Rawslian and Dworkinian constitutional theorist, has incorporated the claims of history and the insights of scholars of American political and constitutional development (and the legal scholars who commune with them) into his otherwise largely 'philosophical' work. He suggests that the essentials of the key portions of that work that he adopts here - about 'is', and the concrete, and 'fit' - were in Dworkin and Rawls (Political Liberalism) all along, a not wholly convincing bit of (creative) mopping up. But this is a matter for intellectual historians. The key point is that, as constitutional theory, what he sets out here, now, seems mostly to work.

\section{HISTORY IN ASPIRATIONALISM/PERFECTIONISM}

While recognizing the uses of history in constitutional argument and justification, Fleming plainly sees the book's take-home point as involving the preeminence of aspiration. Let's focus first on aspirationalism or perfectionism's concessions to history. First is Fleming's acknowledgement of what (following the later Rawls) we may call 'political perfectionism'. 'To be persuasive in our constitutional culture,' Fleming says here, 'one generally needs to argue that one's interpretations fits with the past, shows the past in its best light... or redeems the promises of our abstract moral commitments and aspirations... ${ }^{4}$ He makes clear, however, that this is in no way a concession to originalism (or, at least, to the traditional, 'old-time', hardform originalism of Robert Bork and Antonin Scalia). 'It is a moral reading or philosophic approach that aspires to fidelity to our imperfect Constitution,' ${ }^{5}$ And Fleming criticizes 'constitutional theorists who are not narrow originalists [including his earlier self?]... [for] hav[ing] not paid sufficient attention to how arguments based on history, both adoption history and post-adoption history, function in constitutional law', Here, Fleming highly praises recent work

4 James E. Fleming, Fidelity to Our Imperfect Constitution (Oxford University Press, 2015), 108.

5 Ibid. See William Baude, 'Is Originalism Our Law?' (2015) 116 Columbia Law Review 2349, cited in Fleming (n 4) 136. 
Esta revista forma parte del acervo de la Biblioteca Jurídica Virtual del Instituto de Investigaciones Jurídicas de la UNAM

by Jack Balkin that does precisely this. ${ }^{6}$ He signs on to the criticism by Balkin and his fellow broad originalists of liberals and progressives for ignoring history and ceding it to conservatives. ${ }^{7}$ Fleming is thus now favorably disposed towards historical argument in constitutional debate (and adjudication) if taken to advance a moral reading and not as an alternative to it, with history acting in service to the judges engaging in their primary responsibility of exercising moral judgment. ${ }^{8}$

At the same time, in the new book Fleming distances the constitution-perfecting, aspirationalist theory with which he has long been associated from its longstanding ties to theories of judicial supremacy, and takes a friendly stance toward pluralistic, 'protestant', and departmentalist models of constitutional practice. ${ }^{9}$ He also acknowledges in an unconcerned way the history of the plural forms of justification or multiple modalities that have always been used by judges in their judicial opinions - that is, the observations highlighted in the eclectic accounts of Bobbitt and Fallon-. In doing this, Fleming here distances himself from living constitutionalism as an 'ism'. ${ }^{10}$

Fleming's model, however, retains a clear hierarchy of values, with history in the subservient or instrumental role, honored rather than (necessarily) followed, servant, not rival, to justice. While he certainly affords a role to historical arguments in American constitutionalism, he is express - and emphatic - about their subsidiarity: they are at most minor premises to philosophy's major premises about justice and the nature of the good.

This is problematic. I agree with Fleming's conclusion that fidelity is indispensible to any plausible constitutional theory: I, for one, count this commitment to a duty to fidelity as yet another of origi-

6 J. M. Balkin, 'The New Originalism and the Uses of History' (2013) 82 Fordham Law Review 641.

7 Fleming (n 4) 136-37.

8 Ibid. 91-92.

9 Ibid. 174. See Sanford Levinson, Constitutional Faith (Princeton University Press 1988).

10 Fleming (n 4) 57. 
Esta revista forma parte del acervo de la Biblioteca Jurídica Virtual del Instituto de Investigaciones Jurídicas de la UNAM

ORIGINALISM'S CURIOUSLY TRIUMPHANT DEATH: THE INTERPENETRATION...

nalism's victories — though Fleming insists it was there in Dworkin all along-. ${ }^{11}$ It was, after all, originalists who most centrally and insistently tied the duty of fidelity to the Constitution's status as law, arguing that it was inherent in the very concept of the rule of law (though, to be sure, they were hardly the only to note or mention it). Law as fidelity was originalism's great thrust. ${ }^{12}$

But Fleming's position on history as handmaiden underplays its indispensibility as living constitutionalism's life force. Fleming's failure to afford this reality its due highlights his vestigial monism in a book that breaks new ground in his theoretical project in reconciling itself with constitutional pluralism. Monism is hierarchical. And Fleming's fondness for philosophical clarity, for setting out hypotheses, premises, major and minor, and the like in the form of formal logic, necessarily entails this monistic hierarchy of values in which justice is the major premise and history the minor one. This is, I submit, the wrong way to look at it.

There is a history here that Fleming does not tell in Fidelity to Our Imperfect Constitution, perhaps because that history is about the relationship over time between academic (and particularly legal academic) constitutional theory and party/movement politics driven by an underlying politics of conservativism v. progressivism/ liberalism. While he takes some steps in the direction of emphasizing a non-binary, inter-penetrating complexity, Fleming's hierarchy remains wedded to an ostensibly history-spurning 'living constitutionalism', set in opposition to an aspiration-spurning original-

11 See, e. g., Ronald Dworkin, Law's Empire (Belknap Press 1986).

12 This was true as well for the earlier liberal originalism of Hugo Black, who was disturbed, e. g., by Earl Warren's casual indifference to its rule of law claims in his opinion for the Court in Brown v. Board of Education (1954) 347 U. S. 483, 492-93 ('In approaching this problem, we cannot turn the clock back to 1868, when the Amendment was adopted, or even to 1896, when Plessy v. Ferguson was written. We must consider public education in the light of its full development and its present place in American life throughout the Nation. Only in this way can it be determined if segregation in public schools deprives these plaintiffs of the equal protection of the laws.'). Plessy v. Ferguson (1896) 163 U. S. 537. See more generally Jon Elster, Ulysses and the Sirens (Cambridge University Press 1979); Jon Elster, Ulysses Unbound: Studies in Rationality, Precommitment, and Constraints (Cambridge University Press 2000). 
Esta revista forma parte del acervo de la Biblioteca Jurídica Virtual del Instituto de Investigaciones Jurídicas de la UNAM

KEN I. KERSCH

ism. But this is a relatively contemporary construction, pitting 'ism' against 'ism'. I will discuss conservatism later. But let's take progressivism/liberalism first.

If living constitutionalism is understood as a common modality involving adjustment of constitutional understandings to take into account altered conditions, it, in fact, has a history that dates back to the beginning of the country, and doubtless before - which is why it is easy enough to go back and cherry-pick ancient quotations to hurl at originalist opponents in contemporary constitutional controversies (e. g. 'It is a Constitution we are expounding, adaptable to the various crises of human affairs' ${ }^{13}$. It is also why there is truth underlying David Strauss's model of living constitutionalism as common law constitutionalism. ${ }^{14}$ But living constitutionalism as an 'ism' - that is, as the one right way to do things, as forged against some intransigent, conservative roadblock/barrier school of thought that insisted otherwise - was born in the late nineteenth/early twentieth centuries, and issued from two different and distinctive wellsprings. The first was indubitably morally aspirationalist: it involved aspirationalist conceptions of justice and equality, as read into (typically) the rights provisions of the Civil War Amendments (particularly the Fourteenth) and the invocation in constitutional argument of the natural rights claims of the Declaration of Independence. This aspirationalism was reformist, and reform/social movement aspirationalism, as pioneered by women's rights advocates and abolitionists before the Civil War, maintained its momentum in an ongoing trajectory, following these textual additions, after the War. ${ }^{15}$ While commonly consid-

13 McCulloch v. Maryland (1819) 17 U. S. 316.

14 David A. Strauss, The Living Constitution (Oxford University Press 2010).

15 See Hendrik Hartog, 'The Constitution of Aspiration and "The Rights that Belong to Us All"' (Dec. 1987) 74 Journal of American History 1013; Michael Vorenberg, 'Bringing the Constitution Back In: Amendments, Innovation, and Popular Democracy During the Civil War Era' in Meg Jacobs, William Novak, and Julian Zelizer, editors, The Democratic Experiment: New Directions in American Political History (Princeton University Press 2003); J. David Greenstone, The Lincoln Persuasion: Remaking American Liberalism (Princeton University Press 1993). See also Alexander Tsesis, For Liberty and Equality: The Life and Times of the Declaration of Independence (Oxford University Press 2012). 
Esta revista forma parte del acervo de la Biblioteca Jurídica Virtual del Instituto de Investigaciones Jurídicas de la UNAM

ORIGINALISM'S CURIOUSLY TRIUMPHANT DEATH: THE INTERPENETRATION...

ered an approach of the reformist left, this same moral aspirationalism was applied to the concept of liberty/freedom by the Supreme Court's Lincoln appointees like Justice Stephen Field and subsequent Republican appointees like (Ulysses S. Grant appointee) Joseph Bradley and other 'Lochner era' conservatives. While random natural law claims, of course, dated back to the country's beginning and before (natural law as a modality in a generally pluralist framework) when it was joined with the reform movement thrust of abolitionism, natural law as natural rights became a way of life for many U. S. constitutionalists, and a cause — it became an 'ism' - ${ }^{16}$

The second wellspring of modern living constitutionalism was quite different. This was progressive majoritarianism, premised on a robustly democratic reading of the (best) constitutional order, the very reading Fleming rightly recognizes in the recent work of Sandy Levinson. This democratic/majoritarian living constitutionalism had an anti-legal (or anti-fidelity) thrust, at least as applied to the powers of the courts to police constitutional boundaries.This progressive living constitutionalism came in different forms, of course, from the minimally legalist (Thayer's 'clear mistake' rule, and Holmes's similar approach) to anti-constitutionalist/pure majoritarianism of some of that era, nicely canvassed recently by Aziz Rana - that Fleming rightly recognizes in the recent work of Mike Seidman-. From a populist constitutional perspective, of course, majoritarian-

16 See, e. g., Calder v. Bull (1798) 3 U. S. 386; Fletcher v. Peck (1810) 10 U. S. 87. While an issue in an array of contexts, the problem natural law foundations posed for chattel slavery was always beneath the surface in the early republic, and only rose higher over time. See e. g. Somerset v. Stewart (1772) 98 E.R. 499; United States v. La Jeune Eugenie (1822) 26 F. Cas. 832. See Robert Cover, Justice Accused: Antislavery and the Judicial Process (Yale University Press 1984); Justin Buckley Dyer, Natural Law and the Antislavery Constitutional Tradition (Cambridge University Press 2012). In a recent book, John Compton has provocatively traced the living constitutionalism underlying the expansion of the modern New Deal state to evangelical reformist origins. Oddly, his book largely omits a discussion of abolitionism and slavery, but usefully focuses on late nineteenth century religious reformism as applied to drinking and gambling. National morals regulation as breakthrough/critical juncture to expandings of the powers of the central administrative/social regulatory state. John Compton, The Evangelical Origins of the Living Constitution (Harvard University Press 2014). 
Esta revista forma parte del acervo de la Biblioteca Jurídica Virtual del Instituto de Investigaciones Jurídicas de la UNAM

KEN I. KERSCH

ism can be morally aspirational, with the populace making moral arguments in the public sphere for legislation. But it is not so much a moral reading of the Constitution as a call for the Constitution to get out of the way of the aspiring, perfectionist, justice-seeking people. ${ }^{17}$

There is then the middle ground, which is close to Fleming (and Balkin's) middle ground today, that takes the text as the starting point of constitutional interpretation, but holds that much of the text is either deliberately (or simply factually) broad and indeterminate, and recommends that we should —indeed, must, inevitably - interpret it in light of our current needs, objectives, and aspirations. ${ }^{18}$ Like Jack Balkin today, Woodrow Wilson, writing almost exactly one century before (borrowing, I believe, from Dicey), set out the metaphor of the Constitution as a house that needs to be 'built out' over time. Wilson too wrote about the 'construction zone':

Sometimes, when I think of the growth of our economic system, it seems to me as if, leaving our law just about where it was before any of the modern inventions or developments took place, we had simply at haphazard extended the family residence, added an office here and a workroom there, built up higher on our foundations, and put out little lean-tos on the side, until we have a structure that has no character whatsoever. Now, the problem is to continue to live in the house and yet change it. Well, we are architects in our time, and our architects are also engineers.

17 Sanford Levinson, Our Undemocratic Constitution: Where the Constitution Goes Wrong (And How We the People Can Correct It) (Oxford University Press 2006); James Bradley Thayer, 'The Origin and Scope of the American Doctrine of Constitutional Law' (1893) 7 Harvard Law Review 129. Aziz Rana, 'Progressivism and the Disenchanted Constitution' in Stephen Skowronek, Stephen Engel, and Bruce Ackerman, editors, The Progressives' Century: Democratic Reform and Constitutional Government in the United States (Yale University Press 2016); Louis Michael Seidman, On Constitutional Disobedience (Oxford University Press 2012). There are, of course, moral arguments for democracy, but I will demur on those here. It is worth noting that, while they welcome change and evolution, these two forms of living constitutionalism, the legalist and the anti-legalist, can also be read in stark opposition to each other (see, e. g., Lincoln and his commitment to the equality of natural rights as a representative of the first, and Stephen Douglas, and his commitment to popular sovereignty, as a representative of the second).

18 Charles Beard, 'The Living Constitution' (1936) 185 Annals of the American Academy of Political and Social Science 29. 
Esta revista forma parte del acervo de la Biblioteca Jurídica Virtual del Instituto de Investigaciones Jurídicas de la UNAM

We don't have to stop using a railroad terminal because a new station is being built. We don't have to stop any of the processes of our lives because we are rearranging the structures in which we conduct these processes. What we have to undertake is to systematize the foundations of the house, then to thread all the old parts of the structure with the steel which will be laced together in modern fashion, accommodated to all the modern knowledge of structural strength and elasticity, and then slowly change the partitions, relay the walls, let in the light through new apertures, improve the ventilation; until finally, a generation or two from now, the scaffolding will be taken away, and there will be the family in a great building whose noble architecture will be at last disclosed, where men can live as a single community, co-operative as in a perfected, coordinated beehive, not afraid of any storm of nature, not afraid of any artificial storm, any imitation of thunder and lightning, knowing that the foundations go down to the bedrock of principle, and knowing that whenever they please they can change that plan again and accommodate it as they please to the altering necessities of their lives. ${ }^{19}$

It is notable that all of these first generation of living constitutionalists were famous adepts at embedding their theories in history. They all told stories, stories about the founding, stories about the Civil War, stories about the progress of man. Many, perhaps most, of these stories had a strong patriotic theme (it is worth noting that while Balkin teaches us about construction zones in an academic journal, Wilson set out his theory in public speeches, subsequently assembled into a presidential campaign manifesto, The New Freedom, which he leveraged to win the White House). Progressives, in particular, were highly nationalistic and patriotic. Herbert Croly's New Nationalism, to take just one (triumphant) example, justified change by re-narrating the founding and its relation to necessary changes in the present, calling famously for the achievement of Jeffersonian ends by Hamiltonian means. ${ }^{20}$ None insisted on justice as major premise and history as minor premise: they were two sides of the same coin. This is not unrelated to their ultimate success. Ac-

19 The New Freedom: A Call for the Emancipation of the Generous Energies of a People (Doubleday 1913), 51-52.

20 Herbert Croly, The Promise of American Life (The MacMillan Company 1909). 
Esta revista forma parte del acervo de la Biblioteca Jurídica Virtual del Instituto de Investigaciones Jurídicas de la UNAM

KEN I. KERSCH

cordingly, while Fleming has gone a long way in the right direction, this, in my view, is the next step: his next book should take it.

Although he can't quite break with a monism that makes history the handmaiden of philosophy, Fleming does evince an understanding of this in this book in a way much more pronounced than he ever has before. He acknowledges originalism's appeal not just as a matter of the philosophy of the rule of law, and hermeneutics, but in the U. S. in particular, as a concrete country, with a history and a tradition -indeed, a heritage: what Fleming calls 'our constitutional practice. $^{21}$ He says 'it is... likely that there are contingent reason's for originalism's normative appeal... in the USA.' - as if this 'contingency' itself were a flaw in what would otherwise be the glassy smooth surface of principle, rather than what countries and peoples actually are. $^{22}$ Still, Fleming rightly acknowledges that contemporary originalists, all theories of legal obligation and judicial role and duties aside, are appealing to the constitutional nationalism and 'constitutional patriotism' of Americans, a point earlier noted by both Dorf and Balkin, which Fleming acknowledges and adopts. ${ }^{23}$ While it is worth qualifying this point by remembering that, to some extent this too is a construction - see Michael Kammen's cultural history of Constitution-worship as trajectory, and Madison's efforts to set the public off the scent (to a certain extent) of the sayings and doings of the Founders - it is still very much there, and as much more than just a theory informing approaches to interpretation by professionals. ${ }^{24}$ It is a political vision. When this vision was employed by conservatives to oppose the rulings and reasoning of the liberal, living constitutionalist Warren Court devoted to 'the pursuit of justice', in the (ostensible) defense of an abandoned/betrayed (and, later, a

21 Fleming (n 4) 60.

22 Ibid. 65-66. In this, he is following the path of the later Rawls (of Political Liberalism (Columbia University Press 1993)) as against the earlier Rawls (A Theory of Justice (Belknap Press 1971)), in his own constitutional sphere.

${ }^{23}$ See Dorf (n 2) on 'ancestral' and 'heroic' originalism, as reaffirmed by Balkin (n 5).

24 Michael Kammen, A Machine That Would Go of Itself: The Constitution in American Culture (Knopf 1986). But see David Siemers, Ratifiying the Republic: Antifederalists and Federalists in Constitutional Time (Stanford University Press 2002). 
Esta revista forma parte del acervo de la Biblioteca Jurídica Virtual del Instituto de Investigaciones Jurídicas de la UNAM

'lost' or 'exiled' Constitution), the living constitutionalists were both (initially) triumphant, and set for a major fall. Fleming himself (and Dworkin, Michelman, and the rest) were once very far out on that plank. Fidelity to Our Imperfect Constitution is Fleming's laudable attempt to walk himself back. ${ }^{25}$

And so we get a new seriousness about history, in what Fleming is careful to ascribe as its proper place. His philosophic approach 'would use history for what it teaches rather than for what it purportedly decides for us. In a constructivist world, we would understand that history is a jumble of open possibilities, not authoritative, determinate answers'. ${ }^{26} \mathrm{He}$ gives high praise to 'constructivist' constitutional theory, describing it as the best new work in the field, work that 'acknowledges the place of history, most notably, original meaning, post-adoption history, and precedent, as sources of constitutional interpretation. It recognizes the limitations of history but also appreciates the uses of history (which are different from conventional originalist uses of history)'. Fleming appropriately analogizes this constructivism to the turn taken by Rawls in Political Liberalism, characterizing it as a quest for the best interpretation, with history a part of the quest, while carefully noting that 'History is, can only be, and should only be a starting point in constitutional interpretation. ${ }^{27}$

\section{ASPIRATIONALISM IN HISTORICISM}

Following the scholarship in what I recently learned is a new scholarly literature in 'the history of originalism', Fleming rightly notes that originalism as an 'ism', - as opposed to one longstanding modality of constitutional interpretation, is actually a relatively new

25 See Morton Horwitz, The Warren Court and the Pursuit of Justice: A Critical Issue (Hill and Wang 1998); Speech by William J. Brennan, 'The Constitution of the United States: Contemporary Ratification' (Georgetown University, Oct. 12, 1985). See also Lucas A. Powe, Jr. The Warren Court and American Politics (Belknap Press 2000).

\footnotetext{
26 Fleming (n 4) 22.

27 Ibid. 20.
} 
Esta revista forma parte del acervo de la Biblioteca Jurídica Virtual del Instituto de Investigaciones Jurídicas de la UNAM

KEN I. KERSCH

phenomenon: it essentially begins with Robert Bork, Edwin Meese, and Raoul Berger, forged in reaction to the Warren Court. Part of my own contribution to that new literature, has been to underline the degree to which newish originalism as an 'ism' (what Whittington calls 'old' originalism, and I have called 'reactive' originalism) is only contingently linked to conservatism, theoretically and historically. This old, reactive originalism by the Right represented, in many respects, a revival of majoritarian, democratic, judicial-restraintist, 'clear-mistake' progressivism: the charge against Warren Court liberals by the Old/Reactive originalists was hypocrisy ('you criticized judicial activism and Lochner and judges reading their own politics into law -and, look, you are doing the same thing!'). ${ }^{28}$ In this majoritarian, democracy, anti- or minimally constitutionalist guise, originalism as an ism was the antithesis of aspirationalist/perfectionist moral readings of the Constitution.

In chapter one of Fidelity to Our Imperfect Constitution, Fleming has his own charge of hypocrisy to lodge against contemporary conservative originalists like Michael McConnell, Steven Calabresi, and others, faint-hearted in the face of charges that strict originalism would de-legitimize decisions like Brown v. Board of Education, readings of the Fourteenth Amendment's equal protection clause barring sex discrimination, and/or (for some) due process liberty to protect against sexual orientation discrimination. Fleming charges them with adopting the view, virtually indistinguishable from Dworkin's aspiration/moral concept/conception approach, that purports to be grounded in the authority of these relatively abstract textual constitutional provisions but recognizes, implicitly, that they must be read in light of updated understandings of the requirements of justice, liberty, and equality. ${ }^{29}$ In doing so, these originalists have

28 Lochner v. New York (1905) 198 U. S. 45. Ken I. Kersch, 'Conservatives Remember The Progressive Era' in Skowronek, Engel, and Ackerman, editors, The Progressives' Century; Ken I. Kersch 'Ecumenicalism Through Constitutionalism: The Discursive Development of Constitutional Conservatism in National Review, 1955-1980' (Spring 2011) 25 Studies in American Political Development 86.

29 Baude, 'Is Originalism Our Law?' (n 5). See Michael W. McConnell, 'Originalism and the Desegregation Decisions' (1995) 81 Virginia Law Review 947; Steven Calabresi and Julia Rickert, 'Originalism and Sex Discrimination' (2011) 90 Texas Law Review 1. 
Esta revista forma parte del acervo de la Biblioteca Jurídica Virtual del Instituto de Investigaciones Jurídicas de la UNAM

forfeited the claim for originalism as a stay against (supposedly unconstrained, free-wheeling, subjective/political) living constitutionalism in its moral reading guise. Fleming's argument here is dead-on - exactly right.

The problem, however, is that, as I have emphasized in recent work, conservatives as a group, and conservative constitutionalists, have never claimed to be opposed to moral readings of the Constitution: this opposition is an artifact of constitutional theory as practiced in the law schools by law professors. While that might have seemed to be the world to legal academics, it was never the world of either the wider conservative movement, or even conservative constitutional theorists, many of whom were not law professors, but political scientists and political philosophers.

Of course, the early modern constitutional conservatives, like Justice Field, were aspirationalist moralists about individual liberty: it was Field, after all, who in his Slaughterhouse dissent (1873) insisted on an expansive -indeed, revolutionary- reading the Fourteenth Amendment's new rights provisions. To read it otherwise, Field said, would render the Amendment's adoption 'a vain and idle enactment..30 This is the reason that Justice Hugo Black, who knew whereof he spoke, insisted that any ruling that smacked of Lochnerism amounted to a return to 'natural law'. But there is a much more proximate aspirationalist/moralist conservative constitutionalism to be found in the postwar constitutional theory of the Straussians - of men like Martin Diamond, Harry V. Jaffa, and Walter Berns. These people sometimes disagreed vehemently, at times viciously, about many things (the antagonism between the East Coasters (Allan Bloom and Walter Berns, e. g., and the West Coasters (Jaffa) was especially pronounced). But Straussianism was defined by its insistence on substantive moral ends in politics and constitutionalism, the source of the foundational distinction Straussians drew between ancient and moderns political thinkers (Plato and Aristotle, e. g., versus Machiavelli and Hobbes). These mid-century constitutional theorists were quite explicit in opposing the pure majoritarianism 
Esta revista forma parte del acervo de la Biblioteca Jurídica Virtual del Instituto de Investigaciones Jurídicas de la UNAM

KEN I. KERSCH

and legal positivism they associated with Progressivism. ${ }^{31}$ Since Bork and Scalia's originalism is positivism, and genealogically Progressive, these conservative constitutional theorists have always set themselves in opposition to Bork and Scalia (on the current Court, Clarence Thomas is their man). Let me emphasize that, while these people may be largely unknown to constitutional theorists in the legal academy, they are, and have long been, major thinkers on the constitutional Right. As men trained in political philosophy (mostly) at the University of Chicago, it is worth adding, they brought an immense intellectual sophistication to their constitutional theory: this is not fringe constitutional theory, or lesser constitutional theory, but very serious stuff.

Fleming's focus on the recent updating originalism of McConnell, Calabresi, and others raises a different dimension of all this, and one that sounds in legal theory, intellectual history, and American constitutional development. As a matter of legal theory, this development was inevitable. While it is true that an intransigent fundamentalism which brooks no adjustment or accommodation to change can be surprisingly durable and, to some fanatics, holds an enduring appeal, ${ }^{32}$ this is less than likely to appeal to the mass in a modern liberal democracy (or perhaps even a religion) over the long term. Change will be accommodated: what will be debated is the pace of that change. Any institution or institutional actor charged with in-

31 The same was true of the Roman Catholic constitutional theory of roughly the same period - see John Courtney Murray, S. J., We Hold These Truths: Catholic Reflections on the American Proposition (Sheed and Ward 1960) - it is no coincidence that, these days, many Straussians are housed at Catholic universities). Ken I. Kersch, 'Beyond Originalism: Conservative Declarationism and Constitutional Redemption' (2011) 71 Maryland Law Review 229; Kersch, 'Conservatives Remember' (n 24). See also Edward Purcell, Jr., The Crisis of Democratic Theory: Scientific Naturalism and the Problem of Value (University of Kentucky Press 1973).

32 See, e. g., the problem of Islamic fundamentalism -one of the chief scourges of our time, or the Roman Catholic extreme Right (though even they, conveniently, don't argue today, as Catholic theology once did, that any artificial form of pain relief or sedations, for a headache, surgery, or an excruciating disease, contravened natural law, and the naturalness of human suffering, as lived and exemplified by Christ on the Cross). See Joanna Bourke, The Story of Pain: From Prayer to Painkillers (Oxford University Press 2014). 
Esta revista forma parte del acervo de la Biblioteca Jurídica Virtual del Instituto de Investigaciones Jurídicas de la UNAM

ORIGINALISM'S CURIOUSLY TRIUMPHANT DEATH: THE INTERPENETRATION...

terpreting the law, cleric or jurist, who refuses on principle (in a liberal, democratic state) to accommodate significant social change, to an extent that they arrive at a position wholly divorced from the ambient social order will see his or her authority undermined, just as it would be undermined by the assertion of their authority in a progressive way that takes flight from the law they are charged with interpreting in a way so far in the vanguard as to be divorced from the prevailing social order in precisely the opposite direction. ${ }^{33}$ There have always been conservatives who have recognized this: this, after all, is Burkeanism, the philosophy of prudent, incremental adjustment and reform, such as, e. g., in the constitutional theory of, earlier, Philip Kurland, and, for example, James R. Stoner, Jr. today. Stoner is a political scientist and, once again, if one looks at conservative constitutional theory outside of the law schools where, until very recently, most conservative constitutional theory was written and practiced in modern, postwar U. S. - the opposition between the conservatives and the liberals (e.g. David Strauss) is not all that stark. $^{34}$

But there's more to it than (conservative) Burkeanism. The most prominent postwar non-legal academy constitutional theorists, theorists as visible and influential as Martin Diamond, Walter Berns, and Brent Bozell, were consistent and express in holding that the Constitution would have to be interpreted to take into account social change. As philosophers rather than lawyers (Bozell being the exception), these conservatives preferred subtlety to throwing down the gauntlet on behalf of an extreme and intransigent position and then daring their opponents (as lawyers tend to do) to take a diamet-

33 See Martin Shapiro, Courts: A Comparative and Political Analysis (University of Chicago Press 1986).

34 Philip Kurland, 'A Changing Federalism: American Systems of Laws and Constitution' in Daniel Boorstin, editor American Civilization: A Portrait From the Twentieth Century (McGraw Hill 1972), 127-48; Philip Kurland, Politics, the Constitution, and the Warren Court (University of Chicago Press 1970); James R. Stoner, Jr. Stoner, Common-Law Liberty: Rethinking American Constitutionalism (University Press of Kansas 2003); Stoner, Common Law and Liberal Theory: Coke, Hobbes, and the Origins of American Constitutionalism (University Press of Kansas 1992). 
Esta revista forma parte del acervo de la Biblioteca Jurídica Virtual del Instituto de Investigaciones Jurídicas de la UNAM

rically opposite point of view (e. g. fidelity v. morality). Long before Dorf, Balkin, and Fleming, Martin Diamond argued that we owed the Founders immense respect both because they illuminated the principles upon which our political order rests and because they were learned and wise, but that we are not in any strict way bound by a duty of blind obeisance to follow their dictates. ${ }^{35}$ Viewed in this context, the charge lodged against conservatives that they too are aspirationalists and moral readers, and take into account social change over time is both right and beside the point. It is a very useful point to make as law professors are poised to write the next, and perhaps the final, chapter in the 'ism' v. 'ism' debates that have driven constitutional theory in the law schools for more than a generation. But in the broader ongoing debates between conservative and liberal constitutionalists in politics - in a context in which conservative aspirationalism is ascendant and the concern for 'judicial restraint' is waning - the gotcha charge is likely to be greeted by little more than a shrug. As Reva Seigel and Robert Post have rightly emphasized, the battle now is over the substantive liberal and conservative visions. ${ }^{36}$

\section{CONCLUSION}

Fleming's Fidelity to Our Imperfect Constitution is both highly significant and a sign of the times. Starting from the Dworkinian/aspirationalist/moral perfectionist premises where he has situated his normative constitutional theory across his distinguished career, Jim Fleming has now moved to consider in a sustained way the appropriate place of history constitutional interpretation. While it may be true that, in some sense, the school to which Fleming has long belonged acknowledged history (in its proper place), denied judicial supremacy, accepted the premises of departmentalism, popular constitutionalism, and 'protestant' constitutional pluralism, as Fleming

35 See Kersch 'Conservatives Remember' (n 24); Kersch, 'Ecumenicalism' (n 24).

36 Robert Post and Reva Siegel, "Democratic Constitutionalism," in Jack Balkin and Reva Siegel, editors, The Constitution in 2020 (Oxford University Press 2009), 26. See also Robert Post and Reva Siegel, 'Roe Rage: Democratic Constitutionalism and Backlash' (2007) 42 Harvard Civil Rights-Civil Liberties Law Review 373. 
Esta revista forma parte del acervo de la Biblioteca Jurídica Virtual del Instituto de Investigaciones Jurídicas de la UNAM

ORIGINALISM'S CURIOUSLY TRIUMPHANT DEATH: THE INTERPENETRATION...

staunchly insists here, against longstanding, widespread (and, he insists, mistaken) scholarly perception, moral aspirationalists can certainly not be taken to have been preoccupied or identified with these positions over the years. But in a conservative era these preoccupations and premises have now set the agenda for the field for more than a generation. It is at this point that Fleming, in this book, steps in to, at length, fashion his reckoning with this reality.

In a sense, Fleming here holds the line: aspiration, he argues, is, and must be, primary. Historicism is 'subsidiary', and instrumental, playing a supporting role in the quest for moral perfectionism. My comments here looked at this the other way round, emphasizing, in an empirical and positivist spirit, that aspirationalism and moral perfectionism are history. And they are a particularly prominent part of American history. In interesting ways, they are baked into the core of the American national and constitutional experiment, which is both liberal and providentialist. Moral aspirationalism took center stage with the waxing of disputes over chattel slavery, the Civil War, and the addition of the Constitution's Civil War Amendments. It was the Union victory in the Civil War that launched aspirationalism, constitutional perfectionism, and living constitutionalism as 'isms'. But it wasn't until much later - with the political theory of John Rawls (A Theory of Justice (1971)), the legal theory of Ronald Dworkin (Taking Rights Seriously (1977)), ${ }^{37}$ and their progeny, which prominently includes Fleming himself, that a more rooted, nationalist, patriotic, historically-minded, story-telling and narrating aspirationalism/perfectionism/living constitutionalism insisted in a sustained way that, in the realm of constitutional theory and politics, philosophy was higher and better, and history was lesser and lower. This, of course, was a recipe to both mandarin academic detachment and public irrelevance. Conservative originalists seized upon this presumptuous, self-satisfied detachment, riding the vulnerabilities of Fleming's school all the way to the top, to the point where, as Fleming himself acknowledges, the best new work on constitutional theory (that reaches, by his lights, the right results) starts

37 A Theory of Justice (Belknap Press 1971); Taking Rights Seriously (Harvard University Press 1977). 
Esta revista forma parte del acervo de la Biblioteca Jurídica Virtual del Instituto de Investigaciones Jurídicas de la UNAM

from historicist — and, purportedly, originalist - premises. What Fleming does in Fidelity to Our Imperfect Constitution is make the case that work by Balkin, Amar, Ackerman, and other 'liberal originalists' is actually suffused with — he insists, more formally, starts from - moral or philosophical premises. At the same time, Fleming recognizes the value of liberal originalists attending to history in selling those premises, particularly in American political/constitutional culture. And he emphasizes the degree to which even the best new conservative originalism has also adopted moral, philosophical aspirationalism in taking right results positions on core issues like racial segregation and women's equality, the rejection of which would be politically fraught, if not ultimately de-legitimating and discrediting. Fleming reads these developments as demonstrating that we must now all acknowledge the primary of moral readings of the Constitution.

My conclusion, however, is different. I have noted that the binary between living constitutionalism and historicism that Fleming seeks to transcend here by calling the fight for moral readings, while acknowledging the (instrumental/subsidiary/provisional) significance of historicism, is and has always been false when viewed from the broader perspective of the history and trajectory of U. S. constitutional thought and development and of the contention between progressivism/liberalism and conservatism in the U. S. This binary is an artifact of the hermetic theoretical debates of the mid-to-late twentieth century legal academy, which, in a classically legalist battle, pitted a morally aspirationalist (or majoritarian positivist) living constitutionalism as an 'ism' against a historicist originalism as an 'ism'. Long before this in theory and politics, progressives (especially) and liberals, and even radicals (see the speeches of the anarchist Emma Goldman and the Socialist Eugene V. Debs!), were also robustly historicist, and conservatives - very prominent and influential conservatives, and particularly the leading conservative constitutional theorists (who, in lots of cases, of necessity, given the hegemony of liberalism in mid-to-late twentieth century U. S. law schools, plied their trade outside the law schools) were also aspirationalists and moral perfectionists. The two points of view are, as a matter of fact, and theory, interpenetrating and interpenetrated. They always have 
Esta revista forma parte del acervo de la Biblioteca Jurídica Virtual del Instituto de Investigaciones Jurídicas de la UNAM

been and always will be, at least over the long term, in our actual constitutional life and practice. As such, Fleming's important book both breaks new ground in its prominent attempt at synthesis. But it cannot resist pulling back before a full, and accurate, synthesis to call the fight for the philosophical, moral readings camp. This is an unfortunate conclusion to what is ultimately a thoughtful, timely, and engaging contribution to understanding the way live now in the U. S., and in U. S. constitutional theory.

\section{BIBLIOGRAPHY}

Balkin JM, Constitutional Redemption: Political Faith in an Unjust World (Harvard University Press 2011).

, 'The New Originalism and the Uses of History' (2013) 82 Fordham Law Review 641.

—, and Siegel, R, The Constitution in 2020 (Oxford University Press 2009).

Baude W, 'Is Originalism Our Law?' (2015) 115 Columbia Law Review 2349.

Beard C, 'The Living Constitution' (1936) Annals of the American Academy of Political and Social Science 185: 29-34.

Bickel A, The Least Dangerous Branch: The Supreme Court at the Bar of Politics (Bobbs-Merrill 1962).

Bobbitt P, Constitutional Fate: Theory of the Constitution (Oxford University Press 1982).

Bourke J, The Story of Pain: From Prayer to Painkillers (Oxford University Press 2014).

Brennan W, 'The Constitution of the United States: Contemporary Ratification' (Georgetown University, Oct. 12, 1985).

Calabresi S, \& Rickert J, 'Originalism and Sex Discrimination' (2011) 90 Texas Law Review 1.

Compton J, The Evangelical Origins of the Living Constitution (Harvard University Press 2014). 
Esta revista forma parte del acervo de la Biblioteca Jurídica Virtual del Instituto de Investigaciones Jurídicas de la UNAM

Cover R, Justice Accused: Antislavery and the Judicial Process (Yale University Press 1975).

Croly H, The Promise of American Life (Princeton University Press 2014 [1909]).

Dorf M, 'Integrating Normative and Descriptive Constitutional Theory: The Case of Original Meaning' (1997) 85 Georgetown Law Journal 1765.

Dworkin, R, Taking Rights Seriously (Harvard University Press 1977). , Law's Empire (Belknap Press 1986).

Dyer J, Natural Law and the Antislavery Constitutional Tradition (Cambridge University Press 2012).

Elster J, Ulysses and the Sirens: Studies in Rationality and Irrationality (Cambridge University Press 1979).

,Ulysses Unbound: Studies in Rationality, Precommitment, and Constraints (Cambridge University Press 2000).

Ewick P, and Silbey S, The Common Place of Law: Stories from Everyday Life (University of Chicago Press 1998).

Fallon R, 'A Constructivist Coherence Theory of Constitutional Interpretation' (1987) 100 Harvard Law Review 1189.

Fleming J, Fidelity to Our Imperfect Constitution: For Moral Readings and Against Originalisms (Oxford University Press 2015).

Greenstone JD, The Lincoln Persuasion: Remaking American Liberalism (Princeton University Press 1993).

Hartog $\mathrm{H}$, 'The Constitution of Aspiration and 'The Rights that Belong to Us All' (Dec. 1987) 74 Journal of American History 1013-1034.

Horwitz M, The Warren Court and the Pursuit of Justice: A Critical Issue (Hill \& Wang 1998).

Kammen M, A Machine That Would Go of Itself: The Constitution in American Culture (Knopf 1986).

Kersch KI, 'Ecumenicalism Through Constitutionalism: The Discursive Development of Constitutional Conservatism in National Review, 1955-1980' (Spring 2011) 25 Studies in American Political Development. 
Esta revista forma parte del acervo de la Biblioteca Jurídica Virtual del Instituto de Investigaciones Jurídicas de la UNAM

ORIGINALISM'S CURIOUSLY TRIUMPHANT DEATH: THE INTERPENETRATION...

_ 'Beyond Originalism: Conservative Declarationism and Constitutional Redemption' (2011) 71 Maryland Law Review 229.

, 'Conservatives Remember The Progressive Era' in Ackerman B, Engel S, and Skowronek S, editors, The Progressives' Century: Democratic Reform and Constitutional Government in the United States (2016).

Kramer L, The People Themselves: Popular Constitutionalism and Judicial Review (Oxford University Press 2004).

Kurland P, Politics, the Constitution, and the Warren Court (University of Chicago Press 1970).

,'A Changing Federalism: American Systems of Laws and Constitution' in Boorstin D, ed., American Civilization (McGrawHill 1972).

Levinson S, Constitutional Faith (Princeton University Press 1988). , Our Undemocratic Constitution: Where the Constitution Goes Wrong (And How We the People Can Correct It) (Oxford University Press 2006).

Lovell G, This is Not Civil Rights: Discovering Rights Talk in 1939 America (University of Chicago Press 2012).

Madison J, Hamilton A, and Jay J, The Federalist Papers (Mentor 1999).

McConnell M, 'Originalism and the Desegregation Decisions' (1995) 81 Virginia Law Review 947.

Murray JC, We Hold These Truths: Catholic Reflections on the American Proposition (Sheed and Ward 1960).

Post R, and Siegel R, 'Roe Rage: Democratic Constitutionalism and Backlash’ (2007) 42 Harvard Civil Rights-Civil Liberties Law Review 373.

Post R, and Siegel R, 'Democratic Constitutionalism'” in Balkin JM and Siegel R, eds, The Constitution in 2020 (Oxford University Press 2009).

Powe, Jr. LA, The Warren Court and American Politics (Belknap Press 2000). 
Esta revista forma parte del acervo de la Biblioteca Jurídica Virtual del Instituto de Investigaciones Jurídicas de la UNAM

Purcell Jr. E, The Crisis of Democratic Theory: Scientific Naturalism and the Problem of Value (University of Kentucky Press 1973).

Rana A, 'Progressivism and the Disenchanted Constitution' in Ackerman B, Engel S, and Skowronek S, editors, The Progressives' Century: Democratic Reform and Constitutional Government in the United States (2016).

Rawls J, A Theory of Justice (Belknap Press 1971).

, Political Liberalism (Columbia University Press 1993).

Seidman LM, On Constitutional Disobedience (Oxford University Press 2012).

Shapiro M, Courts: A Comparative and Political Analysis (University of Chicago Press 1986).

Siemers D, Ratifiying the Republic: Antifederalists and Federalists in Constitutional Time (Stanford University Press 2002).

Stoner Jr., J, Common Law and Liberal Theory: Coke, Hobbes, and the Origins of American Constitutionalism (University Press of Kansas 1992).

, Common-Law Liberty: Rethinking American Constitutionalism (University Press of Kansas 2003).

Strauss D, The Living Constitution (Oxford University Press 2010).

Thayer J, "The Origin and Scope of the American Doctrine of Constitutional Law' (1893) 7 Harvard Law Review 129.

Tsesis A, For Liberty and Equality: The Life and Times of the Declaration of Independence (Oxford University Press 2012).

Vorenberg M, 'Bringing the Constitution Back In: Amendments, Innovation, and Popular Democracy During the Civil War Era' in Jacobs M, Novak W, and Zelizer J, eds., The Democratic Experiment: New Directions in American Political History (Princeton University Press 2003).

Wilson W, The New Freedom (Doubleday 1913).

Zackin E, 'Lost Rights and the Importance of Audience (Winter 2013) 41 Tulsa Law Review 421. 
Esta revista forma parte del acervo de la Biblioteca Jurídica Virtual del Instituto de Investigaciones Jurídicas de la UNAM www.juridicas.unam.mx

ORIGINALISM'S CURIOUSLY TRIUMPHANT DEATH: THE INTERPENETRATION...

Cases

Brown v. Board of Education (1954) 347 U.S. 483.

Calder v. Bull (1798) 3 U. S. 386.

Fletcher v. Peck (1810) 10 U. S. 87.

Lochner v. New York (1905) 198 U. S. 45.

McCulloch v. Maryland (1819) 17 U. S. 316.

Plessy v. Ferguson (1896) 163 U.S. 537.

Slaughterhouse Cases (1873) 83 U. S. 36.

Somerset v. Stewart (1772) 98 E.R. 499.

United States v. La Jeune Eugenie (1822) 26 F. Cas. 832. 